\title{
Strategic management in family business. The missing concept of the familiness learning mechanism
}

management in family business

\author{
Ismael Barros-Contreras \\ Instituto de Gestión e Industrias, Universidad Austral de Chile, Valdivia, Chile \\ Rodrigo Basco \\ Sheikh Saoud bin Khalid bin Khalid Al-Qassimi Chair in Family Business, \\ The American University of Sharjah, Sharjah, United Arab Emirates, and \\ Natalia Martín-Cruz and Juan Hernangómez \\ Departamento de Organización de Empresas y Comercialización e Investigación de \\ Mercados, Universidad de Valladolid, Valladolid, Spain
}

\begin{abstract}
Purpose-The purpose of this article is to provide a comprehensive understanding of the roots of family firms' competitive advantages by defining and testing the familiness learning mechanisms that emerge from the interaction between family and firm. Because family members are economically, emotionally and socially attached to the firm, family firms are expected to be able to develop unique and difficult to imitate learning mechanisms related to family firm value creation.

Design/methodology/approach - This study operationalizes and tests the concept of the familiness learning mechanism using a sample of nonlisted Spanish family firms. The sample is analyzed using the structural equation modeling method.

Findings - Results show that family firms' ability to accumulate internal and external knowledge, integrate social knowledge, as well as create and retain socioemotional knowledge forms the concept of the familiness learning mechanism, and the authors show what implications it might have for family firm value creation.

Originality/value - By using the dynamic capabilities approach, this article highlights the importance of the knowledge and learning derived from family involvement in the firm. The creation of learning mechanisms occurs because of the close relationships between family members and their simultaneous participation in the family and in the company systems, which creates a unique context wherein knowledge and learning emerge in an idiosyncratic manner.
\end{abstract}

Keywords Familiness learning mechanism, Knowledge accumulation, Social knowledge integration,

Socioemotional knowledge retention, Family firm

Paper type Research paper

\section{Introduction}

Family business scholars generally assume that the mere presence of family members in the ownership, management and governance spheres (i.e. the demographic approach) can proxy the resources and capabilities derived from family involvement in the firm. In an effort to address this limitation, family firm scholars have focused on defining (Habbershon and Williams, 1999), analyzing (Huybrechts et al., 2011) and testing (Frank et al., 2017) the family firm's unique bundle of resources (familiness). Despite the importance of this research stream for measuring and capturing the resources and capabilities to emerge from family and business interaction, research on familiness has mainly been supported by a static rationality grounded on the resource-based approach which considers familiness as a stock of resources, while ignoring the family effect as a learning mechanism. As a result, we pose the following

Funding: This research was funded by Ministerio de Ciencia e Innovación Español a través del Programa Estatal de Fomento de la Investigación Científica y Técnica de Excelencia, grant number ECO2016-78128-P.
Received 11 October 2019

Revised 8 July 2020 12 August 2020

Accepted 12 August 2020 
research questions: How do family firms build their familiness learning mechanism? Is the familiness learning mechanism related to family firm value creation?

Family resources are necessary, yet by themselves are not sufficient conditions for family firms to develop competitive advantages because they need to be managed effectively (Sirmon and Hitt, 2003) and the organization must develop learning mechanisms in order to sustain them. Stemming from the dynamic capabilities approach (Zollo and Winter, 2002), we argue that the root of family firm competitive advantage resides in the learning mechanisms to emerge from the interaction between family and firm. Specifically, we theorize that learning mechanisms in family firms occur at both business and family level. While the learning processes occurs on a continuum that allows the firm to possess key mechanisms to respond to business and market complexities (Duarte et al., 2019), in family firms, family members, who are economically, emotionally and socially attached to the firm, are expected to be able to develop unique and difficult to imitate learning mechanisms. We develop a conceptual model of familiness learning mechanisms, defined as the family organizational routines that can purposely create, extend and/or modify the unique set of resources and capabilities derived from the interaction between the family, its individual members and the firm, by articulating three main dimensions: internal/external knowledge accumulation, social knowledge integration and socioemotional knowledge retention.

Consequently, this article aims to empirically test the concept of the familiness learning mechanism in an effort to address the paucity of empirical studies and so analyze dynamic capabilities in family businesses (Park et al., 2019). To operationalize the concept in the context of family firms, we use the factor analysis technique and a second-generation technique, partial least squares structural equation modeling (PLS-SEM). We combine confirmatory and structural analyses (Hair et al., 2012) to explore and test the dimensions of the familiness learning mechanism. By using a Spanish sample of family firms, our empirical analysis confirms the proposed three-dimensional concept of the familiness learning mechanism - internal/external knowledge accumulation, social knowledge integration and socioemotional knowledge retention as well as its implications for value creation in family firms.

This article has several theoretical and methodological implications. First, this study contributes to the current discussion surrounding the dynamic capability approach in the strategic management of family business research (Daspit et al., 2018) and it sheds new light which aims to respond to the call made by Zollo and Winter (2002) concerning the limitations of current knowledge vis-à-vis knowing where dynamic capabilities come from. In this sense, in the family firm context, our empirical test shows that the familiness learning mechanism is formed by the overlap between family and firm in terms of internal/external knowledge accumulation, social knowledge integration, and socioemotional knowledge retention and its relationship with family firm value creation. Second, this article attempts to address the current need in the family business field to develop operational concepts (Pearson and Lumpkin, 2011) so as to gain theoretical insights. In this sense, and in empirical terms, this research selects and combines a set of measures and defines specific methods to validate the concept of familiness learning mechanism. Finally, this article also makes practical contributions. The proposed model of familiness learning mechanism could help business families and consultants to better understand where competitive advantages lie and how family and business overlapping may create the learning mechanisms that business families need to manage and, most importantly, hand down from one generation to another.

The article is organized as follows. First, we introduce the theoretical background related to family firm learning mechanisms; second, we explain the methodology used to test the familiness learning mechanism concept; third, we present the results, and finish with the discussion and conclusion. 


\section{Theoretical approach}

What makes a firm a family firm is not only family participation in the ownership, governance and management arenas but also the specific resources and capabilities that emerge from the interaction between family and firm. These resources and capabilities are placed under the general umbrella of the resource-based approach and are referred to as familiness. Familiness is defined as "the unique bundle of resources a particular firm has because of system interaction between the family, its individual members, and the firm" (Habbershon and Williams, 1999, p. 11).

However, the competitive advantages of family firms not only come from familiness, which is the resources that are unique, rare, inimitable and nonsubstitutable, but also from the capacity or capability (Amit and Schoemaker, 1993) to create, accumulate or recombine familiness resources with other resources (physical, human and organizational) into new sources of competitive advantage (Basco et al., 2019). These capacities, called dynamic capabilities, represent "the learned and stable pattern of collective activity through which the organization systematically generates and modifies its operating routines in pursuit of improved effectiveness" (Zollo and Winter, 2002, p. 340). Consequently, dynamic capabilities focus on the learning mechanisms that shape operational routines. Extending this to the context of family firms, learning processes are affected by the interaction between family and firm.

Even though the dynamic capability approach is among the most influential perspectives in management research (Schilke et al., 2018), in the family business field the dynamic capability approach remains underutilized (Daspit et al., 2018) [1] and current research is fragmented. The dynamic capability approach is an adequate framework for family business research, since dynamic capabilities are based on knowledge (Foss, 2005). In the case of family businesses, knowledge and how to manage it, is particularly distinctive compared to nonfamily firms due to the history of common life, affective commitment and family member attachment to the firm (Chirico and Salvato, 2008). There is an overlap between family and business that allows internal/external knowledge accumulation, social integration and retention to be carried out in a particular way, thereby enabling routines that support the learning process to be developed (Duarte and Kok, 2018).

From the dynamic capabilities approach, the familiness learning mechanism can thus be defined as family organizational routines which can purposely create, extend or modify the unique set of resources and capabilities found in a family firm, and which stem from the interaction between the family, its individual members and the firm. Thus, this firm's specific capacity to perceive opportunities and threats allows it to take advantage of opportunities and, finally, to maintain the firm's competitiveness by improving, combining, protecting and, when necessary, reconfiguring the business and its tangible as well as intangible assets (Chirico and Nordqvist, 2010). This familiness learning mechanism relates to the dynamic component that is linked to the family firm's ability to secure strategic generation, strategic adjustment, evolutionary adaptation and wealth creation across generations of the family firm.

We propose that the familiness learning mechanism is a multidimensional formative construct composed of three dimensions: internal and external knowledge accumulation, social knowledge integration [2] and socioemotional knowledge retention (Figure 1).

\subsection{Internal and external knowledge accumulation}

Knowledge accumulation is a process that increases individuals' knowledge within the firm and helps to increase the latter's stock of knowledge. It is accomplished through a complex system of interactions among participants, both inside and outside the organization (Nonaka and Takeuchi, 1995). The accumulation of knowledge is an initial organizational learning mechanism underlying the generation of dynamic capabilities. In family firms, knowledge accumulation is manifested in the wisdom and skills that family members have acquired and
Strategic management in family business 


\section{JFBM}

Figure 1.

"The familiness learning mechanism"

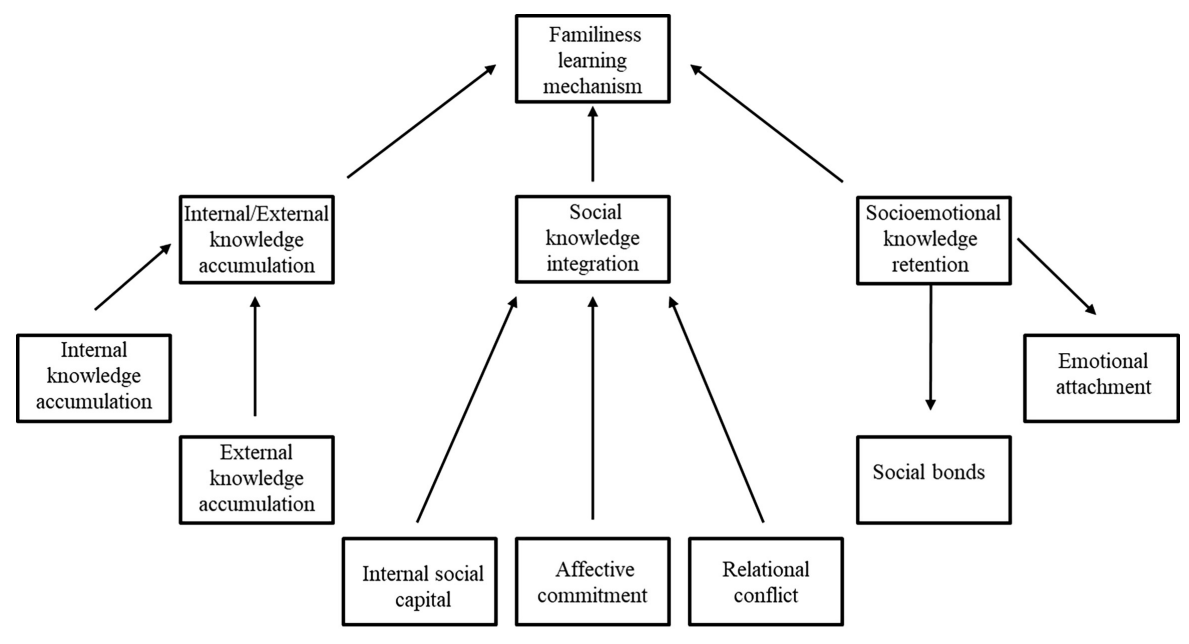

Source(s): Own elaboration

developed through education and experience, both inside and outside the firm (Chirico, 2008). Consistent with Chirico (2008), in family firms, knowledge is better accumulated when family members interact in the firm, are committed to the firm, and participate in "in-house" training courses, all of which enables unique internal knowledge to be generated, created and developed. Nevertheless, internal knowledge must be combined with external knowledge, which happens when family members participate in formal or informal training outside the firm and when talented nonfamily managers are incorporated into the firm. Consequently, the knowledge acquired outside the family firm, when shared and transferred over time within the firm, generates positive advantages for family firm management (Chirico, 2007).

\subsection{Social knowledge integration}

Knowledge integration represents the collective process through which different pieces of specialized knowledge, which the individual possesses, are recombined (Chirico and Salvato, 2008 ) in order to generate collective knowledge and learning. The way that family members integrate both firm and family knowledge and how this is subsequently transferred through generations is crucial to firm survivability. Social knowledge integration is dependent on internal social capital, emotional commitment and relational conflicts (Enberg, 2007).

Internal social capital concerns the current and potential resources that emerge from the network of relationships possessed by individuals (Nahapiet and Ghoshal, 1998) within an organization. Internal social capital encompasses interaction among participants, network ties, trusted relationships, as well as common values and beliefs that facilitate access to large sources of information (Adler and Kwon, 2002) and reduce the time needed to gather, organize and systematize the information required to make decisions. According to Nahapiet and Ghoshal (1998), working together enhances information transmission and allows knowledge absorption among organizational members. Close physical and cognitive proximity, as well as close interaction, facilitates internal learning, allowing family members to integrate information and renew the family firm's capabilities. Thus, when the knowledge has been assimilated, the family is likely to improve a firm's ability to combine and exploit this knowledge (Andersén, 2015). It is the family involvement in the firm which provides specific behavioral and social resources (Pearson et al., 2008). The family structure implicitly possesses the relational and cognitive dimensions characterized by common goals, norms, 
values and experiences which emerge because of kinship relationships. The structure of the family firm, based on the close interaction of ties and mutual trust, thus promotes strong social relationships, which in turn, allows family members to easily integrate their individual expertise and to promote action (Chirico and Salvato, 2008), thereby nurturing the resources and dynamic capabilities owned by the family firm.

Affective commitment is based on an individual's emotional attachment to, identification with and involvement in the organization (Meyer and Allen, 1991). As a result, employees who have a strong affective commitment stay with their organization because they wish to do so (Allen and Meyer, 1996). Thus, the emotional component of commitment captures the affection or fondness for the organization which can be reflected in the extent to which a person belonging to the workforce identifies with the firm (Vallejo, 2009). Due to family-firm interaction based on tie kinship, affective commitment is particularly important in family firms (Herscovitch and Meyer, 2002). Specifically, social integration of knowledge and learning in family firms can be strongly influenced by the emotional commitment of family members to the organization. The affective component of commitment allows family members to identify and align with family firm values. In particular, common work experiences make employees feel psychologically comfortable (Allen and Meyer, 1996), enabling family members to enhance their competences, skills and personal traits such as autonomy, independence and responsibility. Affective commitment encourages individuals to work cooperatively (Herscovitch and Meyer, 2002), promotes social knowledge integration (Beckhard and Dyer, 1983), generates joint or common mindsets as well as strong organizational identity to align between organizational and individual goals, in addition to generating a sense of fairness. All of this speeds up decision making, provides for strategic flexibility, increases long-term oriented relationships, and promotes a collective ability to pursue new opportunities and respond to threats in the competitive environment (Zahra et al., 2008).

Emotional or relational conflicts may result from interpersonal emotional incompatibilities among actors within a group (Jehn, 1995). This reduces mutual understanding, limits competitiveness and causes negative emotional aspects, such as irritation, suspicion and resentment among the members of an organization (Jehn, 1997). In the family firm, intense family member interaction, both in the family and in the firm coupled with the existence of close emotional ties to the family firm, are a potential breeding ground for relational conflicts. Relational conflicts are caused by family evolution and firm development. Family members might have different motivations, values, skills, interests, priorities and levels of closeness in the workplace, which may add to possible disagreements concerning decisions, objectives and other critical aspects of the firm (Gersick et al., 1997). Relational conflict may weaken the potential benefits of group interaction, curtail the effectiveness and efficiency of the organization (Nosé et al., 2017), and therefore delay the integration of individual knowledge (Chirico and Salvato, 2008), the learning process, and the generation of dynamic capabilities. Finally, conflicts in relationships lead family members to fight with one another, rather than to take advantage of the combined use of their knowledge. This results in a lack of family member willingness to share firm information, thereby limiting the growth and performance of the family firm.

\subsection{Socioemotional knowledge retention}

Socioemotional wealth is defined as "the nonfinancial aspects of the firm that meet the family's affective needs, such as identity, the ability to exercise family influence, and the perpetuation of family dynasty" (Gómez-Mejía et al., 2007). This endowment is created by a mechanism that drives family members and stakeholders to share values, beliefs and ideas. In this sense, socioemotional knowledge retention is the common base for group learning and the way to consolidate robust capabilities (Weimann et al., 2020). Family and firm are linked 
by social and emotional aspects which are created by family owners and ipso facto owners who project their identity onto the organization (Berrone et al., 2010). In this context, decisions are taken by combining economic and noneconomic objectives, expectations and priorities (Gómez-Mejía et al., 2011) which generate specific firm- and family orientation (Basco and Pérez Rodríguez, 2009). Thus, building and using socioemotional wealth can enhance family resources and capabilities in the firm and can reconfigure company operational routines (Cepeda and Vera, 2005). Socioemotional wealth, as a family firm learning mechanism, comprises the emotional attachment of family members (Allen and Meyer, 1990; Eddleston and Kellermanns, 2007) and the binding social ties (Cruz et al., 2010; Miller et al., 2009).

Emotional attachment, Bretherton (1985), broadly defines attachment as an emotional tie or psychological bond to a specific object. In this sense, emotional attachment denotes how closely an individual identifies with a group (Paxton and Moody, 2003). Emotional attachment includes a sense of belonging as a key element in an individual's categorical identity, demonstrating that person's cognitive connection to a group (Hogg, 1992) and an individual's positive feeling about such membership (Bollen and Hoyle, 1990). In family firms, the emotional factors stemming from family involvement are a distinctive attribute (Eddleston and Kellermanns, 2007). The emotional attachment of family members to the firm is generated through personal bonding, a common history and past experiences, which influence the development of activities as well as current and future relationships (Berrone et al., 2012), and strengthen family member bonds with the firm, thereby promoting both economic and noneconomic learning. In this context, emotional attachment can promote family member willingness to share experiences and knowledge and thus generate the necessary capabilities to achieve the firm's objectives over time.

Social bonds are built from social networks, which are the key elements in relationships, at both organizational as well as personal levels, in embedded local firms (Johannisson, 1995). Social networks are built and developed through face-to face interaction (Adler and Kwon, 2002). Networks exert a major influence on the firm (Bartlett and Ghoshal, 1995) given that they are the basis of a rich information exchange that enables firms to learn about new alliance and market opportunities with reliable partners (Gulati, 1999). In a family firm context, social bonds are a distinguishing feature because of family member proximity to the community. The embeddedness of the firm within the special context provides particular kinds of conditions for establishing networks and connections. Indeed, reciprocal ties within family firms are not confined exclusively to family members but are likely to extend to a broader set of stakeholders (Miller et al., 2009): community (Arregle et al., 2007), employees, customers (Uhlaner, 2006) and suppliers. For example, long-term relationships with suppliers and customers based on mutual trust make it possible to develop mechanisms to exchange knowledge and to create bridges that connect the firm to its environment.

In summary, we propose that the combination of internal and external knowledge accumulation, social knowledge integration and socioemotional knowledge retention create the conditions to facilitate the unique and difficult to imitate learning mechanisms in the family firm and, consequently, are a source of family firm value creation.

\section{Methodology}

\subsection{Data collection and description of the sample}

We focus our research on the Spanish context to test the research model. In Spain, approximately $90 \%$ of Spanish firms can be considered family firms, and contribute nearly $60 \%$ of the country's gross value added as well as accounting for two-thirds of private employment (Instituto de la Empresa Familiar, 2015). In addition, the majority of Spanish family firms correspond to companies that are not listed on the stock exchange and which are deeply rooted in their communities. From an academic point of view, Spain has a network of 
family business chairs that extends through most universities at a national level. Furthermore, there is a territorial organization set up through associations that group together family businesses by autonomous regions and which depend on the Spanish Family Business Institute at the central level. These characteristics of the Spanish family business system make it a worldwide reference. These aspects were important for this research, since they enabled us to draw on the support of both the Chair of Family Business at the University of Valladolid and the Castilla y León Association of Family Business, in Spain.

Based on the proposed conceptual model of familiness learning mechanisms, listed companies were excluded, because they generally do not maintain the characteristics of familiarity that characterized them in their early stages, and which has been diluted as their ownership has gradually been segmented (Basco and Pérez Rodríguez, 2009), thereby limiting the opportunity for family-business relational ties. In particular, we target nonlisted medium and large family firms, as there is less research on this segment of family firms, with some $80 \%$ of research having focused on listed family firms (Sharma and Carney, 2012).

We select our sample of family firms using the criteria of "the involvement of the family in the firm" used in prior studies (Basco and Pérez Rodríguez, 2011). Consequently, firms need to have one of the following two characteristics to be considered a family firm: (1) family members must participate in firm ownership (at least $50 \%$ of shares must be in family hands) and (2) family members must participate in the governance or in management bodies. We apply these restrictions to the 5,000 largest firms in Spain (Actualidad Económica, 2012). These criteria are met by 1,656 firms.

The survey was prepared in accordance with the literature review related to the study variables included in the research model and was validated in accordance with standard procedures. On the first page of the survey, participants were told that all the information provided would be treated anonymously and confidentially and only used for research purposes. Participants were thus guaranteed total anonymity and confidentiality.

Surveys were sent and received between May and September 2013. A total of 135 surveys were received, representing a response rate of $8.15 \%$. This response rate is similar to that obtained in other studies into family firms (Lindow et al., 2010). There were 125 valid surveys, of which we eliminated 17 because they were identified as nonfamily firms and a further six because they were listed firms, finally resulting in 102 useable surveys.

The useful surveys fitted the research objectives, as $100 \%$ of the sample corresponds to unlisted family businesses in accordance with our first restriction. In addition, and in relation to our second restriction, $99 \%$ of respondents stated that their firms are family-owned, with the presence of family members on their management boards $(95 \%)$ and on their boards of directors $(98 \%)$. Furthermore, $93 \%$ of them expect the future CEO of their firm to be a family member. These aspects are included in the operational definition used of family business (family member involvement in ownership, running and management, and the intention of transgenerational family control).

In order to check for nonresponse bias, we divided the sample into three groups and compared the first responses received with those who responded to the survey last. The underlying assumption is that those who responded later are similar to those who did not respond at all. The completed ANOVA shows statistically insignificant differences between early and late respondents at a $99 \%$ level of significance. Thus, we can confirm that there are no problems with regard to nonresponse bias.

Common method bias could be a potential problem because the predictor and criterion variables were obtained from the same source, as is the case for our database (Podsakoff et al., 2012). Therefore, we first tried to control for common method bias through procedural remedies, specifically when the questionnaires were prepared and during data collection. In addition to these procedural mechanisms, we used a statistical procedure to control for potential common method biases following the suggestions of Podsakoff et al. (2003). First, we 
ran a factor analysis (Harman's single-factor test) by introducing all the variables (independent, dependent and control variables). No method factor emerged, leading us to the conclusion that common method bias is not a problem in this study; i.e. there is no single factor that accounts for the majority of the variance and there is no single general factor that accounts for the majority of variance among variables.

As regards respondents, they were mainly presidents of the board of directors (41\%) and CEOs (31\%), with $86 \%$ of them belonging to the owner's family firm and only $8 \%$ having no ownership of the firm. Of all the respondents, $94 \%$ believe that the firm is a family firm and $93 \%$ wish the future president of the firm to be a family member. The sample obtained was $100 \%$ unlisted family firms participating in the manufacturing industry $(43 \%)$ and services industry (29\%). As for their longevity, $28.4 \%$ of firms in the sample are aged less than 25 years, and $55.9 \%$ have been in the market for ages between 26 and 75 years. As regards size, $34.3 \%$ of firms have between 51 and 250 employees and $51.9 \%$ have over 250 employees.

\subsection{Items, dimensions and constructs}

The construct of familiness learning mechanism is formed (formative construct) by three dimensions: internal/external knowledge accumulation, social knowledge integration and socioemotional knowledge retention. In addition to these three dimensions, we include the organizational effectiveness and perceived firm performance dimensions in the testing model in order to validate the concept of the familiness learning mechanism.

3.2.1 Familiness learning mechanism. Internal and external knowledge accumulation. This first-order factor includes knowledge accumulation processes adapted to family firms and proposed by Chirico (2008). The internal knowledge dimension is measured using a single item related to the family members who work in the firm and who attend practical training courses within the family firm. The external knowledge dimension is measured by using two items: (1) family members working in the firm who attend academic courses or practical training courses outside the firm and (2) the family firm being willing to hire nonfamily member executives. These items were measured using the Likert 1-5 scale.

Social knowledge integration. Social knowledge integration is a second order factor made up of three first-order dimensions. First, for the internal social capital dimension, we adapted the scale proposed by Carr et al. (2011). Items identify family members in the firm who were partners when the firm's global decision-making strategy was planned, who share a vision of what the future of the firm should be, and who have a common view of the firm's mission. Second, for the affective commitment dimension, we adapted the scale proposed by Allen and Meyer (1990). The items identify family members in the firm (1) who feel that their work is challenging and exciting; (2) who know what is expected of them, (3) who feel that the firm does what it commits to do; (4) who perceive a feeling of equity between effort and compensation and (5) who participate in the decision-making process, taking into consideration the firm's work and rules. Finally, relational conflicts were measured with the scale proposed by Jehn (1995). Items identify family members in the firm who have personal problems, apparent behavioral conflicts, who feel tension in relationships, frequently disagree with the opinions of the $\mathrm{CEO}$, are often in conflict with the different opinions presented in the firm, who question the work that each family member does in the firm, and who have different opinions concerning the firm.

3.2.1.1 Socioemotional knowledge retention. Emotional attachment. Emotional attachment is measured by adapting the scales proposed by O'Reilly and Chatman (1986); Allen and Meyer (1990); Carlock and Ward (2001); and Eddleston and Kellermanns (2007). Items identify family members working in the firm for whom (1) protecting the welfare of family members is essential, apart from the personal contributions made to the firm; (2) the bond ties between family members are very strong and (3) emotional considerations are as important as economic considerations. 
Social bonds. We measure social bonds by adapting the scales proposed by Miller and Le Breton-Miller (2005); Miller et al. (2009) and Cruz et al. (2010). Items identify a family firm's relationship with the community, where family members state that (1) relationships with suppliers, customers and employees are based primarily on trust and norms of reciprocity; (2) cooperation with other companies, professional associations, foundations, etc. is important and (3) suppliers' contracts are based on long-term relationships.

3.2.2 Dependent variables. Organizational effectiveness. This variable is built in line with the micro-fundamentals proposed by Teece (2007). Items attempt to identify organizational effectiveness through the development of permanent organizational activities and processes stemming from the firm's learning and knowledge capabilities. The items used are thus related to continuous development: (1) internal research and development activities, (2) activities aimed at identifying changes in customer needs, (3) processes designed to take advantage of technological developments, (4) adaptation processes for the business model, (5) activities such as job rotation, regular multilevel meetings, information bulletins/blogs, configuration of multifunctional teams and (6) processes of resource adaptation to take advantage of new opportunities. These routines have been recognized as evidence of organizational effectiveness (Zheng et al., 2010).

Perceived firm performance. Performance is assessed with the subjective measurement of performance. This measurement was necessary because the firms in our sample were all closely held and because willingness to report objective data could not be guaranteed (Love et al., 2002). We adapted the items proposed by Barnett et al. (2009) and used four performance-related questions regarding how respondents would rate their firm's performance compared to its competitors in (1) growth in sales, (2) growth in market share, (3) growth in number of employees and (4) in return on investment.

\subsection{Model estimation}

To test the concept of the familiness learning mechanism, we estimate a multidimensional concept comprising internal and external knowledge accumulation, social knowledge integration and socioemotional knowledge retention, making up three steps. First, we conduct an exploratory factor analysis using principal component analysis and a varimax rotation. The aim of this first step is to explore the underlying structures of the items and to determine the dimensions that emerge from the data. We use varimax rotation to clearly identify the constructs. Second, through confirmatory factor analysis, we create the firstorder constructs (internal and external knowledge accumulation, internal social capital, affective commitment, relational conflicts, emotional attachment and social bonds), secondorder constructs (internal/external knowledge accumulation, social knowledge integration and socioemotional knowledge retention) and the third-order construct (familiness learning mechanism). PLS-SEM is used to analyze the construct validity of the dimensions that emerge from the factor analysis, given its strength as an exploratory technique.

Third, following the partial least squares model of structural equations (PLS), we validate our model in which we introduce the dependent dimensions (organizational effectiveness and perceived firm performance) to test the consequences of the familiness learning mechanism construct. The measurement and structural parameters are estimated via an iterative procedure that combines simple and multiple regressions by traditional ordinary least squares, thus avoiding any distributional assumption of the observed variables. Consequently, PLS does not suffer from the indeterminacy problems associated with other modeling techniques and does not require data normality (Wittmann et al., 2009). All firstorder constructs are reflective. As regards the second-order factors, while two of them (knowledge accumulation and socioemotional knowledge retention) are reflective, social knowledge integration is formative. Finally, the concept of familiness learning mechanism is modeled as a formative third-order construct. 
We use PLS to validate our model (Ringle et al., 2005) (see Figure 2). PLS-SEM is increasingly being used in the administration, strategy and marketing research fields (Bontis et al., 2007; Drengner et al., 2008; Gruber et al., 2010; Sattler et al., 2010) as well as for family firms (Segaro et al., 2014; Vallejo, 2009). Recent studies stress the usefulness of the PLS model as a research tool in the field of family firms (Binz et al., 2014; Sarstedt et al., 2014). It is more suitable for early stages of theory development and can support exploratory and confirmatory research (Premkumar and Bhattacherjee, 2008), fundamental complex research, as well as studies in which theoretical knowledge is scarce (Wold, 1982). The software used is Smart PLS 2.0 (Ringle et al., 2005).

The estimation process using PLS is completed through simple and multiple regressions. To run PLS regressions, the sample must meet the requirements of the most complex multiple regression (Barclay et al., 1995), which is determined by multiplying by 10 the highest result of (1) the number of indicators of the most complex formative construct or (2) the highest number of structural paths directed toward any of the model's constructs (Chin, 1998). Our sample of 102 observations is suitable for the estimation process. Before the structural model estimation is completed, confirmatory factor analysis is conducted to verify the measurement model of the familiness learning mechanism.

\section{Results}

\subsection{Exploratory factor analysis}

In order to obtain good item reliability, the load must be higher than 0.7 (Carmines and Zeller, 1979). For each of the six factors, all loadings are above 0.7, with the exception of two in the

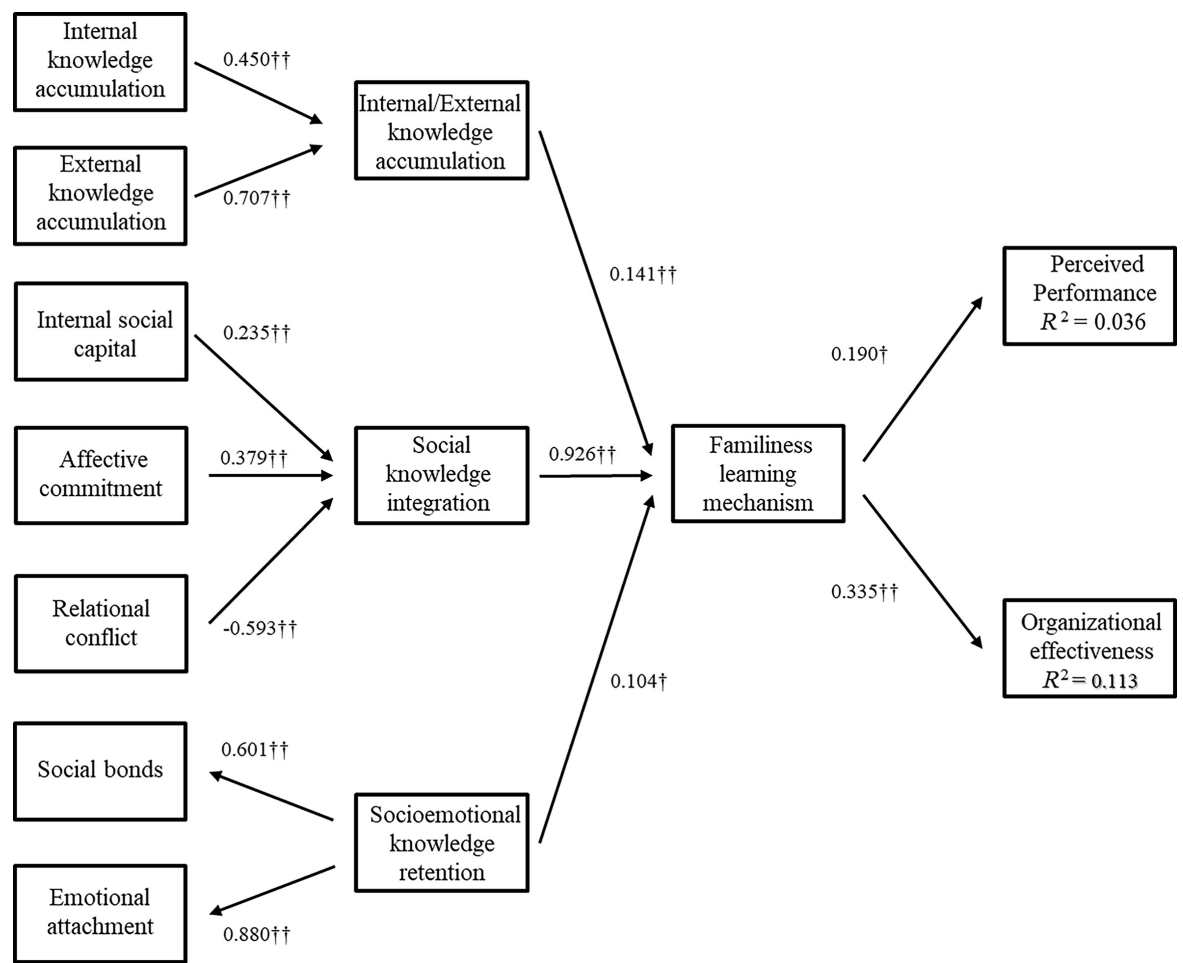

Figure 2.

Structural model 
social bonds construct, which have loads close to 0.7 , a measurement still considered acceptable in the early stages of theory development (Chin, 1998) (Table 1).

\subsection{Confirmatory factor analysis}

First-order factor confirmatory analysis. Confirmatory factor analysis supports the measurement model by clearly identifying the constructs (first-order analysis) that make up the family firm learning mechanism. In PLS, the reflective indicators are determined by the construct and covariate at this level (Hulland, 1999). Table 2 summarizes the parameters of first-order confirmatory factor analysis. The measurement model is evaluated by studying each item's reliability, internal consistency as well as convergent validity and discriminant validity (Roldán and Leal, 2003). The internal reliability of each item is determined by item loadings and is expressed as the percentage of item variance relative to the construct. As observed in the exploratory factor analysis, all loadings are above 0.7 , with the exception of two in the social bonds construct, which have loads close to 0.7 .

The internal consistency of the constructs is evaluated by determining Cronbach's alpha and composite reliability. The indicators exceed 0.7 for Cronbach's alpha and 0.8 for composite reliability, indicating that both measurements are acceptable (Nunnally, 1978). The convergent validity of the construct is expressed in the degree that all the items in a construct are measured by the same concept and is evaluated by examining the average variance extracted (AVE). In our analysis, the AVE indicator exceeds the 0.5 recommended by Fornell

\begin{tabular}{|c|c|c|c|c|c|c|c|c|}
\hline & $\begin{array}{l}\text { Factor 1: } \\
\text { relation } \\
\text { conflict }\end{array}$ & $\begin{array}{c}\text { Factor 2: } \\
\text { affective } \\
\text { commitment }\end{array}$ & $\begin{array}{c}\text { Factor 3: } \\
\text { internal } \\
\text { social } \\
\text { capital } \\
\end{array}$ & $\begin{array}{l}\text { Factor 4: } \\
\text { emotional } \\
\text { attachment }\end{array}$ & $\begin{array}{c}\text { Factor 5: } \\
\text { internal } \\
\text { knowledge } \\
\text { accumulation }\end{array}$ & $\begin{array}{c}\text { Factor 6: } \\
\text { external } \\
\text { knowledge } \\
\text { accumulation }\end{array}$ & $\begin{array}{c}\text { Factor 7: } \\
\text { social } \\
\text { bonds } \\
\end{array}$ & \\
\hline $\begin{array}{l}\text { Cronbach's } \\
\text { alpha }\end{array}$ & 0.894 & 0.825 & 0.785 & 0.748 & - & 0.523 & 0.537 & \\
\hline $\begin{array}{l}\text { coefficients } \\
\text { Explained } \\
\text { variance }\end{array}$ & 0.30 & 0.11 & 0.09 & 0.07 & - & 0.07 & 0.05 & \\
\hline \multicolumn{9}{|l|}{ Items } \\
\hline Relcon_1 & 0.862 & & & & & & & \\
\hline Relcon_2 & 0.835 & & & & & & & \\
\hline Relcon_3 & 0.802 & & & & & & & \\
\hline Relcon_4 & 0.732 & & & & & & & \\
\hline Relcon_5 & 0.803 & & & & & & & \\
\hline Relcon_6 & 0.737 & & & & & & & \\
\hline Relcon_7 & 0.702 & & & & & & & \\
\hline Affcom_1 & & 0.722 & & & & & & \\
\hline Affcom_2 & & 0.786 & & & & & & \\
\hline Affcom_3 & & 0.819 & & & & & & \\
\hline Affcom_4 & & 0.734 & & & & & & \\
\hline Affcom_5 & & 0.772 & & & & & & \\
\hline Intsoccap_1 & & & 0.814 & & & & & \\
\hline Intsoccap_2 & & & 0.858 & & & & & \\
\hline Intsoccap_3 & & & 0.835 & & & & & \\
\hline Emoatt_1 & & & & 0.817 & & & & \\
\hline Emoatt_2 & & & & 0.785 & & & & \\
\hline Emoatt_3 & & & & 0.844 & & & & \\
\hline Intknoacc_1 & & & & & 1.000 & & & \\
\hline Extknoacc_1 & & & & & & 0.879 & & \\
\hline Extknoacc_2 & & & & & & 0.758 & & \\
\hline Socbon_1 & & & & & & & 0.691 & \\
\hline Socbon_2 & & & & & & & 0.819 & Table 1. \\
\hline Socbon_3 & & & & & & & 0.642 & Factor analysis \\
\hline
\end{tabular}


JFBM

\begin{tabular}{|c|c|c|c|c|c|}
\hline Construct/indicator & $\begin{array}{c}\text { Factor } \\
\text { loading / }\end{array}$ & $t$-statistic & $\begin{array}{c}\text { Composite } \\
\text { reliability }\end{array}$ & AVE & $\begin{array}{c}\text { Cronbach's } \\
\text { alpha }\end{array}$ \\
\hline $\begin{array}{l}\text { Internal social capital } \\
\text { Intsoccap_1 } \\
\text { Intsoccap_2 } \\
\text { Intsoccap_3 }\end{array}$ & $\begin{array}{l}0.814 \\
0.858 \\
0.835\end{array}$ & $\begin{array}{l}15.701 \\
26.529 \\
17.340\end{array}$ & 0.874 & 0.700 & 0.785 \\
\hline $\begin{array}{l}\text { Affective commitment } \\
\text { Affcom_1 } \\
\text { Affcom_2 } \\
\text { Affcom_3 } \\
\text { Affcom_4 } \\
\text { Affcom_5 }\end{array}$ & $\begin{array}{l}0.722 \\
0.786 \\
0.819 \\
0.734 \\
0.772\end{array}$ & $\begin{array}{l}10.275 \\
16.470 \\
25.339 \\
14.401 \\
18.494\end{array}$ & 0.877 & 0.589 & 0.825 \\
\hline $\begin{array}{l}\text { Relational conflict } \\
\text { Relcon_1 } \\
\text { Relcon_2 } \\
\text { Relcon_3 } \\
\text { Relcon_4 } \\
\text { Relcon_5 } \\
\text { Relcon_6 } \\
\text { Relcon_7 }\end{array}$ & $\begin{array}{l}0.862 \\
0.835 \\
0.802 \\
0.732 \\
0.803 \\
0.737 \\
0.702\end{array}$ & $\begin{array}{l}25.039 \\
24.813 \\
13.754 \\
10.778 \\
16.964 \\
14.942 \\
11.389\end{array}$ & 0.917 & 0.614 & 0.894 \\
\hline $\begin{array}{l}\text { Internal knowledge } \\
\text { accumulation } \\
\text { Intknoacc_1 }\end{array}$ & 1.000 & - & - & - & - \\
\hline $\begin{array}{l}\text { External knowledge } \\
\text { accumulation } \\
\text { Extknoacc_1 } \\
\text { Extknoacc_2 } \\
\text { Social bonds } \\
\text { Socbon_1 } \\
\text { Socbon_2 } \\
\text { Socbon_3 }\end{array}$ & $\begin{array}{l}0.879 \\
0.758 \\
\\
0.691 \\
0.819 \\
0.642\end{array}$ & $\begin{array}{r}39.766 \\
8.209 \\
\\
4.032 \\
7.994 \\
3.859\end{array}$ & 0.803 & 0.673 & 0.523 \\
\hline $\begin{array}{l}\text { Emotional attachment } \\
\text { Emoatt_1 } \\
\text { Emoatt_2 } \\
\text { Emoatt_3 }\end{array}$ & $\begin{array}{l}0.817 \\
0.785 \\
0.844\end{array}$ & $\begin{array}{l}19.865 \\
18.649 \\
18.278\end{array}$ & 0.856 & 0.665 & 0.748 \\
\hline $\begin{array}{l}\text { Organizational effectiveness } \\
\text { Orgeff_1 } \\
\text { Orgeff_2 } \\
\text { Orgeff_3 } \\
\text { Orgeff_4 } \\
\text { Orgeff_5 } \\
\text { Orgeff_6 }\end{array}$ & $\begin{array}{l}0.712 \\
0.890 \\
0.802 \\
0.801 \\
0.693 \\
0.872\end{array}$ & $\begin{array}{r}9.035 \\
18.989 \\
9.932 \\
14.578 \\
6.219 \\
14.675\end{array}$ & 0.913 & 0.637 & 0.888 \\
\hline $\begin{array}{l}\text { Perceived firm performance } \\
\text { Perfirper_1 } \\
\text { Perfirper_2 } \\
\text { Perfirper_3 } \\
\text { Perfirper_4 }\end{array}$ & $\begin{array}{l}0.930 \\
0.807 \\
0.670 \\
0.790\end{array}$ & $\begin{array}{l}0.879 \\
5.788 \\
4.810 \\
3.596 \\
4.941\end{array}$ & 0.647 & 0.822 & \\
\hline
\end{tabular}

Table 2.

First-order confirmatory factor analysis 
and Larcker (1981) (Table 2). Discriminant validity is evaluated by examining the degree to which the square root of the AVE is higher than the corelated interconstruct (Table 3).

Second-order confirmatory factor analysis. Confirmatory factor analysis supports the measurement model by identifying the representative factors of the learning mechanisms (second-order analysis). The constructs of internal/external knowledge accumulation and social knowledge integration are modeled formatively, and socioemotional knowledge retention is modeled reflectively. We follow the same analysis sequence. Table 4 shows that outer weights which belong to their respective dimensions of each learning mechanism are significant, confirming that the fit of the formative measurement model is good. The outer loadings confirm the same fit for socioemotional knowledge creation. Next, we check for multicollinearity using the variance inflation factor (VIF). The values are below 5 , indicating no collinearity concerns.

Third-order confirmatory factor analysis. Confirmatory factor analysis supports the measurement model by clearly identifying the representative factors of the familiness learning mechanism (third-order analysis). The results of the analysis show that outer weights are significant, confirming the fit of the reflective model - Table 4 . The VIF values indicate there are no collinearity concerns.

\subsection{Structural model}

Figure 2 shows the explained variance $\left(R^{2}\right)$ in the dependent constructs and the $\beta$ path coefficients for the model. In line with Chin (1998), bootstrapping (1,000 samples) is used to generate standard errors and $t$-statistics. The $R^{2}$ values for the dependent variables are 0.113 , and 0.036 for organizational effectiveness and perceived firm performance, respectively. Figure 2 shows that the familiness learning mechanism positively and significantly influences ordinary capabilities with a coefficient of $0.335(t=4.415)$ and perceived firm performance with a coefficient of $0.190(t=2.329)$.

\begin{tabular}{|c|c|c|c|c|c|c|c|c|c|}
\hline & 1 & 2 & 3 & 4 & 5 & 6 & 7 & 8 & 9 \\
\hline $\begin{array}{l}\text { 1. Affective } \\
\text { commitment }\end{array}$ & 0.767 & & & & & & & & \\
\hline $\begin{array}{l}\text { 2. Perceived firm } \\
\text { performance }\end{array}$ & 0.164 & 0.804 & & & & & & & \\
\hline $\begin{array}{l}\text { 3. Emotional } \\
\text { attachment }\end{array}$ & -0.755 & -0.034 & 0.815 & & & & & & \\
\hline $\begin{array}{l}\text { 4. Internal social } \\
\text { capital }\end{array}$ & 0.011 & -0.029 & -0.068 & 0.837 & & & & & \\
\hline $\begin{array}{l}\text { 5. Internal } \\
\text { knowledge } \\
\text { accumulation }\end{array}$ & -0.331 & 0.152 & 0.441 & -0.027 & 1.000 & & & & \\
\hline $\begin{array}{l}\text { 6. External } \\
\text { knowledge } \\
\text { accumulation }\end{array}$ & -0.476 & 0.001 & 0.679 & 0.002 & 0.615 & 0.820 & & & \\
\hline $\begin{array}{l}\text { 7. Organizational } \\
\text { effectiveness }\end{array}$ & -0.006 & 0.222 & -0.030 & -0.030 & 0.177 & -0.023 & 0.798 & & \\
\hline $\begin{array}{l}\text { 8. Relational } \\
\text { conflict }\end{array}$ & 0.222 & 0.370 & -0.054 & 0.535 & -0.053 & -0.001 & -0.058 & 0.784 & \\
\hline 9. Social bonds & -0.753 & -0.024 & 0.797 & -0.011 & 0.436 & 0.682 & -0.024 & -0.023 & 0.721 \\
\hline
\end{tabular}

Table 3. First-order construct correlations and average variance extracted (AVE)

Note(s): Diagonal elements are the square root of AVE 


\section{JFBM}

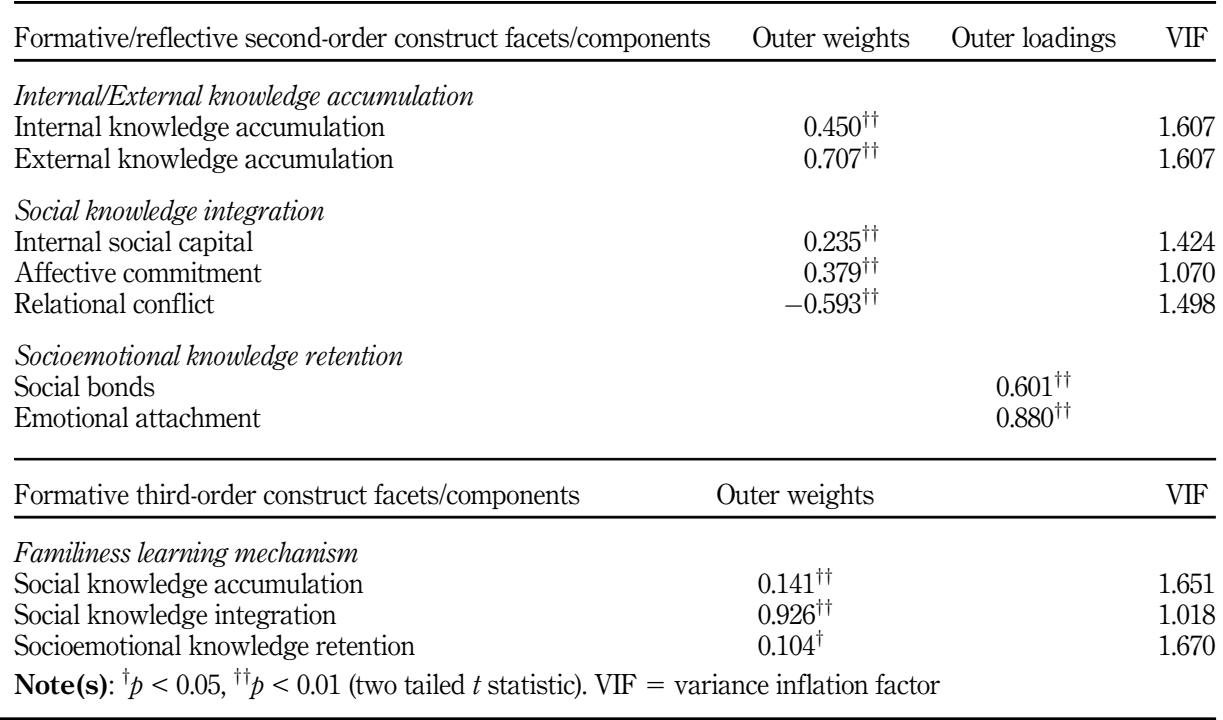

\section{Discussion and conclusion}

Previous research on family firms suggests that family participation in the firm is the source of idiosyncratic resources and capabilities (Habbershon and Williams, 1999). However, the way these resources and capabilities are produced and handed down from generation to generation requires further inquiry. The resources and capabilities created by the interactions between family and firm (familiness) do not fully explain the internal mechanisms that really occur within family business boundaries. The firm needs to be able to generate dynamic capabilities through its learning mechanisms so that the family firm's resources can be created and recombined. In this sense, our research seeks to theoretically position and empirically test the concept of the familiness learning mechanism. Following Daspit et al. (2018), we use the dynamic capabilities approach in the proposed conceptualization of the familiness learning mechanism to shed light on the importance of knowledge and learning derived from family involvement in the firm.

We argued that the close relationships between family members and their simultaneous participation in the family and the firm's systems creates a unique context where knowledge and learning occur in an idiosyncratic manner, allowing the creation of a familiness learning mechanism. In this sense, we proposed that the familiness learning mechanism includes an accumulation of internal and external knowledge, social knowledge integration and the retention of socioemotional knowledge. Family firms possess specific conditions to integrate and recombine knowledge and to develop emotional and social mechanisms to preserve this knowledge. This knowledge becomes part of a firm's specialized knowledge and skills, enabling superior company value creation and long-term success (Duarte and Kok, 2018).

Our model proposes that the combination of three specific mechanisms emerging from the overlap between family and business creates familiness learning mechanisms. The first mechanism is related to the accumulation of internal and external knowledge. In line with Chirico (2008, p. 451), "knowledge accumulation is viewed as an enabler of longevity in family businesses, in which learning emerges through an evolutionary process that begins in the family and continues both inside and outside the business". In this sense, knowledge 
accumulation becomes the starting point for general internal and external knowledge to be internalized (Chirico and Salvato, 2016), through its absorption, and to be transformed into organizational learning. Thus, the internal knowledge acquired by family members, mainly in the shape of tacit knowledge obtained through experience and learning by doing, is combined with the skills and knowledge obtained by family members through training and work outside the family business. This accumulation of knowledge is idiosyncratic in family business and is based on family members' high levels of emotional attachment and psychological ownership with the firm. The challenge is to accumulate and convey this knowledge to future family generations as a source of dynamic capabilities and competitive advantage for family businesses (Boyd et al., 2015).

The second mechanism, once the internal/external knowledge is accumulated, concerns the need to integrate and absorb the knowledge and to effectively manage it. Social knowledge integration comprises three elements: internal social capital, affective commitment and relational conflict. First, our results show that internal social capital is positively related to knowledge integration (Chirico and Salvato, 2008). The dynamics of knowledge integration largely depends on the social context within an organization (Kusunoki et al., 1998). Family firms are characterized by intense social relationships among family members, which occur both inside and outside the family firm context (Chirico and Salvato, 2008). These relationships are developed within the family member interactions and mutual trust through which ideas and orientations are more likely to be shared (Sirmon and Hitt, 2003). The common affiliation of family members with the family and firm creates a united family group (Ling and Kellermanns, 2010) and thus, an ideal social context to support the social integration of knowledge. Second, affective commitment is positively related to the social integration of knowledge. Family firms in which there is strong family member commitment to the firm are more flexible than firms in which such a commitment is not relevant (Zahra et al., 2008). This flexibility is generated through social knowledge integration processes which shape the organization's capabilities, allowing for changes to be quickly adapted to, new customer demands to be met, emerging technologies to be adopted or developed and new markets to be defined (Volberda, 1996). Committed family members adapt their behavior so that it is consistent with the spirit of change, focusing their mentality on the results and, therefore, on knowledge integration (Chirico and Salvato, 2008).

Finally, the third element of social knowledge integration is relational conflict. In line with the extant literature (Eddleston et al., 2008), this relational conflict is negatively related to knowledge integration. Interpersonal family conflicts create negative feelings among family members, increase negative reactions and make family members indifferent to the family (Chirico and Salvato, 2008), limiting the exchange of information, given the reduction in mutual understanding between individuals which is essential for knowledge integration (Eddleston and Kellermanns, 2007). Taken together, these findings extend the studies of Chirico and Salvato $(2008,2016)$ by showing that knowledge integration is central to organizational learning and a critical aspect of company success. The use of family members' specialized knowledge in family businesses depends to a great extent on their affective commitment and the intensity and quality of their interactions. Therefore, the family business can benefit from the positive aspects of familiness and can effectively promote the integration of knowledge and learning, allowing the development of capabilities over time.

The third mechanism is related to the feelings and emotions that permeate strategic decision-making. Indeed, the organizational learning process is influenced by socioemotional endowments. Therefore, the knowledge accumulated and integrated into family businesses includes the intention to create and maintain the socioemotional wealth that the family deposits in the firm. This socioemotional knowledge transmits family values and beliefs to the firm over time, significantly contributing to the idiosyncratic process of knowledge management and learning, and thus to dynamic capability generation in the family firm 
(Weimann et al., 2020). The retention of socioemotional knowledge involves social bonds and emotional attachment. Family firms are usually integrated into the communities in which they participate (Berrone et al., 2010). The closeness and stability of family members' relations with the community are based on trust and, in the long term, promote communication and information exchange (Miller and Le Breton-Miller, 2005). Moreover, the emotional attachment that family members feel for the firm leads them to make an additional effort, and to share their experiences and knowledge in order to secure long-term survival (Berrone et al., 2012). The socioemotional retention of knowledge within the family firm is part of the familiness learning mechanism.

The internal/external accumulation, the social integration and the socioemotional retention of knowledge form the concept of the familiness learning mechanism. The familiness learning mechanism leverages the idiosyncratic resources created by family influence through knowledge and learning management. This allows the family firm to pinpoint and take advantage of opportunities from the environment and to create new knowledge that is integrated and combined through socioemotional interactions over time (Cabrera-Suárez et al., 2018), thereby contributing to organizational effectiveness and performance. The familiness learning mechanism adds vitality to the family's influence on the firm and ensures the dynamic orchestration of the family firm (Barros et al., 2016). In particular, this organizational learning capability, derived from the family's participation in the firm, is the hidden and intangible process built with the feelings and emotions of family members, and which shapes the use of knowledge to achieve both economic and noneconomic objectives.

\section{Theoretical and practical implications \\ 6.1 Theoretical implications}

The concept of familiness learning mechanism presented and tested in this article has two theoretical implications. First, from a theoretical point of view, it extends the literature on dynamic capabilities by answering, on the one hand, the calls made by Zollo and Winter (2002) to improve current knowledge on the origin of dynamic capabilities and, on the other, by expanding the study of dynamic capabilities in family businesses (Chirico and Salvato, 2008, 2016; Daspit et al., 2018; Duarte and Kok, 2018; Duarte et al., 2018, 2019; Park et al., 2019). In addition, as regards the call made by Barros et al. (2016), we present an empirical analysis aimed at explaining how family businesses are able to adjust their organizational routines by developing the familiness learning mechanism. Specifically, the organizational routines of internal/external accumulation of knowledge, social integration of knowledge and socioemotional knowledge retention allow organizational knowledge to be conveyed through generations. These organizational learning routines have a special application in the family business, due to the common life history among family members that reinforces their affective and emotional ties with the firm, allowing the knowledge management process to develop in an idiosyncratic way (Duarte and Kok, 2018), and to support the process of generating dynamic capabilities in family businesses. Additionally, from the strategic management point of view, this study furthers current understanding of how family businesses learn (Astrachan, 2010; Daspit et al., 2017), particularly vis-à-vis the adjustment between family resources and learning mechanisms for efficient strategic management. This offers more insights into the analysis of business strategy and decision-making in family businesses (Basco, 2014; Basco et al., 2020).

Finally, from a methodological perspective, this article addresses the need to develop operational concepts to measure constructs/dimensions in the family firm arena (Pearson and Lumpkin, 2011). This research empirically selects and combines a set of already used measures and defines specific methods to validate the concept of the familiness learning 
mechanism. In this sense, our article overcomes the limitation which assumes that family firms possess certain competitive advantages by trying to measure what makes family firms different. We propose a measure to capture familiness learning mechanisms by integrating three aspect of knowledge management; namely, accumulation of new knowledge, integration of existing knowledge, and the importance of socioemotional knowledge to retain new and accumulating knowledge.

\subsection{Practical contributions}

This study has implications for the management of family businesses. The growth of the family and the advancement of family generations requires continuous adaptation, with the management of family relationships, values and culture proving vital for its continuity as a business family. Therefore, it is essential for family and nonfamily managers to recognize that family dynamics can influence family firms, specifically in the process of strategic decisions. In this way, understanding the causes and consequences of the organizational processes of knowledge accumulation, social knowledge integration and retention of socioemotional knowledge can allow managers to organize and prepare family firms to deal with the idiosyncratic knowledge management that derives from family influence. When approaching such an aim, managers need to foster a collaborative environment to exchange information and knowledge, especially tacit knowledge, in order to support the learning process. In this sense, it is necessary for managers to deploy their efforts in order to create an environment of trust and commitment that facilitates interaction and favors the transmission of knowledge with its socioemotional components, with the latter being elements that support the familiness learning mechanism in family businesses.

\section{Limitations and further research}

This research represents a first quantitative approach to measuring dynamic capabilities in the family firm arena and offers important implications. However, we recognize that our research may have certain inevitable limitations that must be considered and which may limit the interpretation of our results. First, this is a cross-sectional study, an issue which proves particularly problematic when it comes to measuring phenomena over time. The static nature of this type of study does not allow causality relationships to be established, thus making it impossible to capture the dynamic essence. Future studies should work on overcoming this limitation by conducting longitudinal research. Second, the application of surveys in data collection may be questionable, although the characteristics of the study made it necessary to apply such an instrument. Applying qualitative methodologies, such as analyzing specific case studies, could complement our results with new descriptive information to build theory. Third, another methodological limitation involves obtaining data based on the subjective evaluation of a principal informant, which may lead to common method bias. Even though this is controlled, additional procedures and methodological improvements are needed in order to have more than one respondent per firm.

The study also posits some interesting future lines of research. For example, efforts might be geared toward identifying the evolution and impact of the familiness learning mechanism on a family firm's strategy over time and capturing its dynamic essence. The results to emerge from this study constitute merely an initial attempt to better understand the learning mechanisms that emerge in family firms. Nevertheless, the use of qualitative methodologies may provide greater detail for theory building. Finally, future research might seek to evaluate our model in other contexts, thereby contributing to its adaptation and/or generalization.

\section{Notes}

1. Some exceptions include the works of Chirico and Salvato (2008, 2016); Chirico et al. (2012); Daspit et al. (2018); Duarte and Kok (2018); Duarte et al. (2018, 2019) and Park et al. (2019).
Strategic management in family business 
2. In dynamic capabilities literature, the commonly used term is articulation of knowledge (Zollo and Winter, 2002). However, in the field of the family firm, the term used is integration of knowledge (Chirico and Salvato, 2008). In our research, we use the concept of integration of knowledge and assimilate it to that of articulation of knowledge.

\section{References}

Actualidad Económica (2012), 5000 Mayores Empresas de España, Unidad Editorial Internet, Madrid.

Adler, P. and Kwon, S.W. (2002), "Social capital: prospects for a new concept", Academy Management Review, Vol. 27 No. 1, pp. 17-40.

Allen, N.J. and Meyer, J., P. (1990), "The measurement and antecedents of affective, continuance and normative commitment to the organization”, Journal of Occupational Psychology, Vol. 63 No. 1, pp. 1-18.

Allen, N.J. and Meyer, J.P. (1996), "Affective, continuance, and normative commitment to the organization: an examination of construct validity", Journal of Vocational Behavior, Vol. 49 No. 3, pp. 252-276.

Amit, R. and Schoemaker, P.J.H. (1993), "Strategic assets and organizational rent", Strategic Management Journal, Vol. 14 No. 1, pp. 33-46.

Andersén, J. (2015), "The absorptive capacity of family firms: how familiness affects potential and realized absorptive capacity”, Journal of Family Business Management, Vol. 5 No. 1, pp. 73-89.

Arregle, J.L., Hitt, M.A., Sirmon, D.G. and Very, P. (2007), "The development of organizational social capital: attributes of family firms", Journal of Management Studies, Vol. 44 No. 1, pp. 73-95.

Astrachan, J.H. (2010), "Strategy in family business: toward a multidimensional research agenda", Journal of Family Business Strategy, Vol. 1 No. 1, pp. 6-14.

Barclay, D., Higgins, C. and Thompson, R. (1995), "The partial least squares (PLS) approach to causal modeling: personal computer adoption and use as an illustration”, Technology Studies, Vol. 2 No. 2, pp. 285-309.

Barnett, T., Eddleston, K. and Kellermanns, F.W. (2009), "The effects of family versus career role salience on the performance of family and nonfamily firms", Family Business Review, Vol. 22 No. 1, pp. 39-52.

Barros, I., Hernangómez, J. and Martin-Cruz, N. (2016), "A theoretical model of strategic management of family firms. a dynamic capabilities approach”, Journal of Family Business Strategy, Vol. 7 No. 3, pp. 149-159.

Bartlett, C. and Ghoshal, S. (1995), Transnational Management: Texts, Cases and Readings CrossBorders in Cross-Border Management, Irwin, Homewood, IL.

Basco, R. (2014), "Exploring the influence of the family upon firm performance: does strategic behaviour matter?”, International Small Business Journal, Vol. 32 No. 8, pp. 967-995.

Basco, R. and Pérez Rodríguez, M.J. (2009), "Studying the family enterprise holistically evidence for integrated family and business systems”, Family Business Review, Vol. 22 No. 1, pp. 82-95.

Basco, R. and Pérez Rodríguez, M.J. (2011), "Ideal types of family business management: horizontal fit between family and business decisions and the relationship with family business performance", Journal of Family Business Strategy, Vol. 2 No. 3, pp. 151-165.

Basco, R., Calabrò, A. and Campopiano, G. (2019), "Transgenerational entrepreneurship around the world: implications for family business research and practice", Journal of Family Business Strategy, Vol. 10 No. 4, pp. 10-16.

Basco, R., Rodriguez Escudero, A.I., Martin-Cruz, N. and Barros-Contreras, I. (2020), "The combinations of market and non-market strategies that facilitates family firm survival", Entrepreneurship Research Journal, forthcoming, doi: 10.1515/erj-2019-0258.

Beckhard, R. and Dyer, W.G.J. (1983), "Managing continuity in the family-owned business", Organizational Dynamics, Vol. 12 No. 1, pp. 5-12. 
Berrone, P., Cruz, C., Gómez-Mejía, L.R. and Larraza-Kintana, M. (2010), "Socioemotional wealth and corporate responses to institutional pressures: do family-controlled firms pollute less?", Administrative Science Quarterly, Vol. 55 No. 1, pp. 82-113.

Berrone, P., Cruz, C. and Gómez-Mejía, L.R. (2012), "Socioemotional wealth in family firms: theoretical dimensions, assessment approaches, and agenda for future research", Family Business Review, Vol. 25 No. 3, pp. 258-279.

Binz, C., Patel, V.K. and Wanzenried, G. (2014), "A comparative study of CB-SEM and PLS-SEM for theory development in family firm research", Journal of Family Business Strategy, Vol. 5 No. 1, pp. 116-128.

Bollen, K.A. and Hoyle, R.H. (1990), "Perceived cohesion: a conceptual and empirical examination", Social Forces, Vol. 69 No. 2, pp. 479-504.

Bontis, N., Booker, L.D. and Serenko, A. (2007), "The mediating effect of organizational reputation on customer loyalty and service recommendation in the banking industry", Management Decision, Vol. 45 No. 9, pp. 1426-1445.

Boyd, B., Royer, S., Pei, R. and Zhang, X. (2015), "Knowledge transfer in family business successions: implications of knowledge types and transaction atmospheres", Journal of Family Business Management, Vol. 5 No. 1, pp. 17-37.

Bretherton, I. (1985), "Attachment theory: retrospect and prospect", Monographs of the Society for Research in Child Development, Vol. 50 Nos 1-2, pp. 3-35.

Cabrera-Suárez, M.K., García-Almeida, D.J. and De Saá-Pérez, P. (2018), “A dynamic network model of the successor's knowledge construction from the resource- and knowledge-based view of the family firm", Family Business Review, Vol. 31 No. 2, pp. 178-197.

Carlock, R.S. and Ward, J.L. (2001), Strategic Planning for the Family Business: Parallel Planning to Unify the Family and Business, Palgrave, Houndsmill, NY.

Carmines, E.G. and Zeller, R.A. (1979), Reliability and Validity Assessment, Vol. 17, Sage, Thousand Oaks, CA.

Carr, J.C., Cole, M.S., Ring, J.K. and Blettner, D.P. (2011), "A measure of variations in internal social capital among family firms", Entrepreneurship: Theory and Practice, Vol. 35 No. 6, pp. 1207-1227.

Cepeda, G. and Vera, D. (2005), "Knowledge management and firm performance: examining the mediating link of dynamic capabilities", 4th International Meeting of the Iberoamerican Academy of Management, Lisbon, Portugal.

Chin, W.W. (1998), "The partial least squares approach for structural equation modeling”, in GA, M. (Ed.), Modern Methods for Business Research, Lawrence Erlbaun Associates, Mahwah, NJ, pp. 295-336.

Chirico, F. (2007), "The accumulation process of knowledge in family firms", Electronic Journal of Family Business Studies, Vol. 1 No. 1, pp. 62-90.

Chirico, F. (2008), "Knowledge accumulation in family firms: evidence from four case studies", International Small Business Journal, Vol. 26 No. 4, pp. 433-462.

Chirico, F. and Nordqvist, M. (2010), "Dynamic capabilities and trans-generational value creation in family firms: the role of organizational culture", International Small Business Journal, Vol. 28 No. 5 , pp. 487-504.

Chirico, F. and Salvato, C. (2008), "Knowledge integration and dynamic organizational adaptation in family firms", Family Business Review, Vol. 21 No. 2, pp. 169-181.

Chirico, F. and Salvato, C. (2016), "Knowledge internalization and product development in family firms: when relational and affective factors matter", Entrepreneurship: Theory and Practice, Vol. 40 No. 1, pp. 201-229. 
Chirico, F., Nordqvist, M., Colombo, G. and Mollona, E. (2012), "Simulating dynamic capabilities and value creation in family firms: is paternalism an 'asset' or 'liability'?", Family Business Review, Vol. 25 No. 3, pp. 318-338.

Cruz, C.C., Gómez-Mejía, L.R. and Becerra, M. (2010), "Perceptions of benevolence and the design of agency contracts: CEO - TMT relationships in family firms", Academy of Management Journal, Vol. 53 No. 1, pp. 69-89.

Daspit, J.J., Chrisman, J.J., Sharma, P., Pearson, A.W. and Long, R.G. (2017), "A strategic management perspective of the family firm: past trends, new insights, and future directions", Journal of Managerial Issues, Vol. 29 No. 1, pp. 6-29.

Daspit, J.J., Long, R.G. and Pearson, A.W. (2018), "How familiness affects innovation outcomes via absorptive capacity: a dynamic capability perspective of the family firm", Journal of Family Business Strategy, Vol. 10 No. 2, pp. 133-143.

Drengner, J., Gaus, H. and Jahn, S. (2008), "Does flow influence the brand image in event marketing?", Journal of Advertising Research, Vol. 48 No. 1, pp. 138-147.

Duarte, A. and Kok, S. (2018), "Adapting through learning and knowledge acquisition: the cases of four global family firms", Journal of Family Business Management, Vol. 8 No. 3, pp. 274-292.

Duarte, A., Kok, S. and O'Shea, M. (2018), "Family businesses and adaptation: a dynamic capabilities approach", Journal of Family and Economic Issues, Vol. 39 No. 4, pp. 683-698.

Duarte, A., Kok, S. and O'Shea, M. (2019), "The family business, adversity and change: a dynamic capabilities and knowledge-based approach", Journal of General Management, Vol. 44 No. 2, pp. 96-109.

Eddleston, K.A. and Kellermanns, F.W. (2007), "Destructive and productive family relationships: a stewardship theory perspective”, Journal of Business Venturing, Vol. 22 No. 4, pp. 545-565.

Eddleston, K.A., Otondo, R.F. and Kellermanns, F.W. (2008), "Conflict, participative decision-making, and generational ownership dispersion: a multilevel analysis", Journal of Small Business Management, Vol. 46 No. 3, pp. 456-484.

Enberg, C. (2007), Knowledge Integration in Product Development Projects, Dissertations from IMIE No 106 Doctoral Dissertation Institutionen för Ekonomisk, Linköping Universitet, Linköping.

Fornell, C. and Larcker, D.F. (1981), "Evaluating structural equation models with unobservable variables and measurement error", Journal of Marketing Research, Vol. 18 No. 1, pp. 39-50.

Foss, N.J. (2005), Strategy, Economic Organization, and the Knowledge Economy: The Coordination of Firms and Resources, Oxford University Press, New York, NY.

Frank, H., Kessler, A., Rusch, T., Suess-Reyes, J. and Weismeier-Sammer, D. (2017), "Capturing the familiness of family businesses: development of the family influence familiness scale (FIFS)", Entrepreneurship: Theory and Practice, Vol. 41 No. 5, pp. 709-742.

Gersick, K.E., Davis, J.A., McCollom, M. and Lansberg, I. (1997), Generation to Generation Life Cycles of the Family Business, Harvard Business School Press, Boston, MA.

Gómez-Mejía, L.R., Haynes, K.T., Núñez-Nickel, M., Jacobson, K.J.L. and Moyano-Fuentes, J. (2007), "Socioemotional wealth and business risks in family-controlled firms: evidence from Spanish olive oil mills", Administrative Science Quarterly, Vol. 52 No. 1, pp. 106-137.

Gómez-Mejía, L.R., Cruz, C., Berrone, P. and De Castro, J. (2011), "The bind that ties: socioemotional wealth preservation in family firms", The Academy of Management Annals, Vol. 5 No. 1, pp. 653-707.

Gruber, M., Heinemann, F., Brettel, M. and Hungeling, S. (2010), "Configurations of resources and capabilities and their performance implications: an exploratory study on technology ventures", Strategic Management Journal, Vol. 31 No. 12, pp. 1337-1356.

Gulati, R. (1999), "Network location and learning: the influence of network resources and firm capabilities on alliance formation”, Strategic Management Journal, Vol. 20 No. 5, pp. 397-420.

Habbershon, T.G. and Williams, M.L. (1999), "A resource-based framework for assessing the strategic advantages of family firms", Family Business Review, Vol. 12 No. 1, pp. 1-25. 
Hair, J.F., Sarstedt, M., Pieper, T.M. and Ringle, C.M. (2012), "The use of partial least squares structural equation modeling in strategic management research: a review of past practices and recommendations for future applications”, Long Range Planning, Vol. 45 Nos 5-6, pp. 320-340.

Herscovitch, L. and Meyer, J.P. (2002), "Commitment to organizational change: extension of a threecomponent model”, Journal of Applied Psychology, Vol. 87 No. 3, pp. 474-487.

Hogg, M.A. (1992), The Social Psychology of Group Cohesiveness: From Attraction to Social Identity, New York University Press, New York, NY.

Hulland, J. (1999), "Use of partial least squares (PLS) in strategic management research: a review of four recent studies", Strategic Management Journal, Vol. 20 No. 2, pp. 195-204.

Huybrechts, J., Voordeckers, W., Vandemaele, S. and Lybaert, N. (2011), "The distinctiveness of family-firm intangibles: a review and suggestions for future research", Journal of Management and Organization, Vol. 17 No. 2, pp. 268-287.

Instituto de la Empresa Familiar (2015), La Empresa Familiar en España, Instituto de la Empresa Familiar, Madrid.

Jehn, K.A. (1995), "A multimethod examination of the benefits and detriments of intragroup conflict", Administrative Science Quarterly, Vol. 40 No. 2, pp. 256-282.

Jehn, K.A. (1997), “A qualitative analysis of conflict types and dimensions in organizational groups", Administrative Science Quarterly, Vol. 42 No. 3, pp. 530-557.

Johannisson, B. (1995), "Paradigms and entrepreneurial networks-some methodological challenges", Entrepreneurship and Regional Development, Vol. 7 No. 3, pp. 215-232.

Kusunoki, K., Nonaka, I. and Nagata, A. (1998), "Organizational capabilities in product development of Japanese firms: a conceptual framework and empirical findings", Organization Science, Vol. 9 No. 6, pp. 699-718.

Lindow, C.M., Stubner, S. and Wulf, T. (2010), "Strategic fit within family firms: the role of family influence and the effect on performance", Journal of Family Business Strategy, Vol. 1 No. 3, pp. 167-178.

Ling, Y. and Kellermanns, F.W. (2010), "The effects of family firm specific sources of TMT diversity: the moderating role of information exchange frequency", Journal of Management Studies, Vol. 47 No. 2, pp. 322-344.

Love, L.G., Priem, R.L. and Lumpkin, G.T. (2002), "Explicitly articulated strategy and firm performance under alternative levels of centralization”, Journal of Management, Vol. 28 No. 5, pp. 611-627.

Meyer, J.P. and Allen, N.J. (1991), "A three-component conceptualization of organizational commitment”, Human Resource Management Review, Vol. 1 No. 1, pp. 61-89.

Miller, D. and Le Breton-Miller, I. (2005), Managing for the Long Run: Lessons in Competitive Advantage from Great Family Businesses, Harvard Business School Press, Boston, MA.

Miller, D., Lee, J., Chang, S. and Breton-Miller, I.L. (2009), "Filling the institutional void: the social behavior and performance of family vs non-family technology firms in emerging markets", Journal of International Business Studies, Vol. 40 No. 5, pp. 802-817.

Nahapiet, J. and Ghoshal, S. (1998), "Social capital, intellectual capital, and the organizational advantage”, Academy Management Review, Vol. 23 No. 2, pp. 242-266.

Nonaka, I. and Takeuchi, H. (1995), The Knowledge-Creating Company: How Japanese Companies Create the Dynamics of Innovation, Oxford University Press, New York.

Nosé, L., Korunka, C., Frank, H. and Danes, S.M. (2017), "Decreasing the effects of relationship conflict on family businesses: the moderating role of family climate", Journal of Family Issues, Vol. 38 No. 1, pp. 25-51.

Nunnally, J.C. (1978), Psychometric Theory, 2nd ed., McGraw-Hill, New York, NY.

O'Reilly, C. and Chatman, J. (1986), "Organizational commitment and psychological attachment: the effects of compliance, identification, and internalization on prosocial behavior", Journal of Applied Psychology, Vol. 71 No. 3, pp. 492-499. 
Park, H.Y., Misra, K., Reddy, S. and Jaber, K. (2019), "Family firms' innovation drivers and performance: a dynamic capabilities approach", Journal of Family Business Management, Vol. 9 No. 1, pp. 4-23.

Paxton, P. and Moody, J. (2003), "Structure and sentiment: explaining emotional attachment to group", Social Psychology Quarterly, Vol. 66 No. 1, pp. 34-47.

Pearson, A.W. and Lumpkin, G.T. (2011), "Measurement in family business research", Family Business Review, Vol. 24 No. 4, pp. 287-291.

Pearson, A.W., Carr, J.C. and Shaw, J.C. (2008), "Toward a theory of familiness: a social capital perspective", Entrepreneurship: Theory and Practice, Vol. 32 No. 6, pp. 949-969.

Podsakoff, P.M., MacKenzie, S.B., Lee, J.-Y. and Podsakoff, N.P. (2003), "Common method biases in behavioral research: a critical review of the literature and recommended remedies", Journal of Applied Phycology, Vol. 88 No. 5, pp. 879-903.

Podsakoff, P.M., MacKenzie, S.B. and Podsakoff, N.P. (2012), "Sources of method bias in social science research and recommendations on how to control it", Annual Review of Psychology, Vol. 63 No. 1, pp. 539-569.

Premkumar, G. and Bhattacherjee, A. (2008), "Explaining information technology usage: a test of competing models", Omega, Vol. 36 No. 1, pp. 64-75.

Ringle, C.M., Wende, S. and Will, S. (2005), SmartPLS 2.0 (M3), University of Hamburg, Hamburg.

Roldán, J.L. and Leal, A. (2003), A Validation Test of an Adaptation of the DeLone and McLean's Model in the Spanish EIS fieldCritical Reflections on Information Systems. A Systemic Approach, Idea Group, London, pp. 66-84.

Sarstedt, M., Ringle, C.M., Smith, D., Reams, R. and Hair, J.F. Jr (2014), "Partial least squares structural equation modeling (PLS-SEM): a useful tool for family business researchers", Journal of Family Business Strategy, Vol. 5 No. 1, pp. 105-115.

Sattler, H., Völckner, F., Riediger, C. and Ringle, C.M. (2010), "The impact of brand extension success drivers on brand extension price premiums", International Journal of Research in Marketing, Vol. 27 No. 4, pp. 319-328.

Schilke, O., Hu, S. and Helfat, C.E. (2018), "Quo vadis, dynamic capabilities? a content-analytic review of the current state of knowledge and recommendations for future research", Academy of Management Annals, Vol. 12 No. 1, pp. 390-439.

Segaro, E.L., Larimo, J. and Jones, M.V. (2014), "Internationalisation of family small and medium sized enterprises: the role of stewardship orientation, family commitment culture and top management team”, International Business Review, Vol. 23 No. 2, pp. 381-395.

Sharma, P. and Carney, M. (2012), "Value creation and performance in private family firms: measurement and methodological issues", Family Business Review, Vol. 25 No. 3, pp. 233-242.

Sirmon, D.G. and Hitt, M.A. (2003), "Managing resources: linking unique resources, management, and wealth creation in family firms", Entrepreneurship: Theory and Practice, Vol. 27 No. 4, pp. 339-358.

Teece, D.J. (2007), "Explicating dynamic capabilities: the nature and microfoundations of (sustainable) enterprise performance", Strategic Management Journal, Vol. 28 No. 13, pp. 1319-1350.

Uhlaner, L.M. (2006), "Business family as a team: underlying force for sustained competitive advantage", in Poutziouris, K.X.S.P.Z. and Klein, S.B. (Eds), Handbook of Research on Family Business, Edward Elgar, Cheltenham, pp. 125-144.

Vallejo, M. (2009), "The effects of commitment of non-family employees of family firms from the perspective of stewardship theory", Journal of Business Ethics, Vol. 87 No. 3, pp. 379-390.

Volberda, H.W. (1996), "Toward the flexible form: how to remain vital in hypercompetitive environments", Organization Science, Vol. 7 No. 4, pp. 359-374.

Weimann, V., Gerken, M. and Hülsbeck, M. (2020), "Business model innovation in family firms: dynamic capabilities and the moderating role of socioemotional wealth", Journal of Business Economics, Vol. 90 No. 3, pp. 369-399. 
Wittmann, C.M., Hunt, S.D. and Arnett, D.B. (2009), "Explaining alliance success: competences, resources, relational factors, and resource-advantage theory", Industrial Marketing Management, Vol. 38 No. 7, pp. 743-756.

Wold, H. (1982), "Systems under indirect observation using PLS", in , F C (Ed.), A Second Generation of Multivariate Analysis, Praeger, New York, NY, Vol. I Method, pp. 325-347.

Zahra, S.A., Hayton, J.C., Neubaum, D.O., Dibrell, C. and Craig, J. (2008), "Culture of family commitment and strategic flexibility: the moderating effect of stewardship", Entrepreneurship: Theory and Practice, Vol. 32 No. 6, pp. 1035-1054.

Zheng, W., Yang, B. and McLean, G.N. (2010), "Linking organizational culture, structure, strategy, and organizational effectiveness: mediating role of knowledge management", Journal of Business Research, Vol. 63 No. 7, pp. 763-771.

Zollo, M. and Winter, S.G. (2002), "Deliberate learning and the evolution of dynamic capabilities", Organization Science, Vol. 13 No. 3, pp. 339-351.

\section{Corresponding author}

Ismael Barros-Contreras can be contacted at: ismael.brrs@gmail.com

For instructions on how to order reprints of this article, please visit our website: 